Archives of Agriculture and Environmental Science

\title{
Assessment of the ichthyofaunal diversity in the Juri River of Sylhet district, Bangladesh
}

\author{
Md. Rashidul Islam, Mrityunjoy Kunda* (D) , Debasish Pandit, and Ahmed Harun-Al-Rashid \\ Department of Aquatic Resource Management, Sylhet Agricultural University, Sylhet-3100, BANGLADESH \\ "Corresponding author's E-mail: kunda.sau@gmail.com
}

\section{ARTICLE HISTORY}

Received: 27 November 2019

Revised received: 02 December 2019

Accepted: 05 December 2019

\section{Keywords}

Diversity

Fish species

Ichthyofauna

Juri River

Threatened species

\section{ABSTRACT}

This study was conducted to assess the present status of ichthyofaunal assemblages in the Juri River of Fenchuganj upazila in Sylhet district, Bangladesh. Survey works were made in three different locations of the river during May to December, 2018 comprising direct fish catch observations, questionnaire interviews, focus group discussions with fishers, fish traders, aratders (wholesalers) and river bank community members, and key informant interviews with upazila fisheries officer, district fisheries officer, non-governmental organization officials, and local leaders. The results revealed that a total of 75 species of fishes under 25 families were available. Among these species 11 were commonly available, 32 were moderately available, 25 were less available, and 7 were rarely available. Cyprinidae was the leading family consisting of $27 \%$ of the total fish population of the study area. However, 10 vulnerable, 8 endangered and 1 critically endangered fish species were also found in small amount. During this study the highest number of species (61) was found in the catches in October and lowest number of species (22) was recorded in July. According to the perceptions of fishers and resource person degradation of habitat, climate change, and human activities are the triggering agents for declining ichthyofaunal diversity in this river. Therefore, this study recommends application of proper management measures including community participation to conserve the ichthyofaunal diversity and enhance fish production in the Juri River.

(C)2019 Agriculture and Environmental Science Academy

Citation of this article: Islam, M.R. Kunda, M., Pandit, D. and Harun-Al-Rashid, A. (2019). Assessment of the ichthyofaunal diversity in the Juri River of Sylhet district, Bangladesh. Archives of Agriculture and Environmental Science, 4(4): 488-496, https://dx.doi.org/10.26832/24566632.2019.0404016

\section{INTRODUCTION}

Bangladesh is blessed with vast and diversified fisheries resources which include rivers, estuaries, beels, haors, baors (ox-bow lakes), floodplains, and huge area of marine water resources (DoF, 2018). These productive water resources support many fish species which ultimately afford the country's total fisheries production (Shamsuzzaman et al., 2017). Throughout the world fish form an indispensable part of the daily food intake. Fish and fisheries have become a vital part of Bangladeshi diets from ancient time and presently play a dynamic role in nutrition supply, employment generation, foreign currency earnings and other economic aspects of the country (DoF, 2018; Hossain, 2014). However, many fish species in the natural waterbodies are under different levels of threats.
During the last century, riverine ecosystems have endured from passionate human intervention, resulting in habitat degradation and loss of aquatic ecosystems. Consequently, many fish species have become highly threatened, particularly in rivers where substantial demand is placed on freshwaters (Rahman et al., 2012). According to IUCN (2015), there are 253 species of inland freshwater fishes; among those 9 species are critically endangered (CR), 30 species are endangered (EN), 25 species are vulnerable (VU), and 27 species are near threatened (NT), 122 species are least concern (LC), and the rest 40 species are considered data deficient (DD) throughout the country. Due to overharvesting, degradation of habitat and consequent declining fish production from natural waterbodies, contribution of inland capture fisheries has been reduced from $50 \%$ to $35 \%$ of annual fisheries production, and production of marine capture 
fisheries has remained static over the last decade (Mazid, 2010). Overfishing, siltation, indiscriminate fishing of larvae and juveniles, and water pollution are recognized as the major worries linked with the declination of ichthyofaunal diversity (Islam et al., 2015a).

The Juri River is one of the important waterbodies in the northeastern part of Bangladesh in terms of fish production and income generation of many fishermen surrounding that wetland. This river originated from the hilly region of the Tripura state of India and enters into Bangladesh towards Dharmanagar at Kulaura upazila of Maulvibazar district. Another vital flow of this river named the Sonai River also originated from India and joins to this river at Sonai-Bardan point and their joint flow supports a rich diversity of fishes in the surrounding waterbody. The Juri River flows through the Hakaluki haor at different upazila in Maulvibazar district and falls into the Kushiyara River at Fenchuganj upazilas of Sylhet district. In the monsoon season it merges with the flooded Hakaluki haor. Due to these circumstances the Juri River is very significant for the availability of diversified aquatic species, especially fishes, and believed to be an essential spawning and feeding ground for haor and riverine fish species.

Maximum number of wild populations have been disappeared from the rivers and streams of Bangladesh due to overexploitation augmented by various environmental changes and degradation of the natural habitat (Galib et al., 2009, 2013). Nowadays, gradual reduction of aquatic biodiversity from natural waterbodies is a vital problem in Bangladesh (Galib et al., 2009, 2013; Imteazzaman and Galib, 2013; Chaki et al., 2014; Mohsin et al., 2013, 2014). These brief discussions indicate the necessity for in-depth study of biodiversity which is essential to assess the present status and sustainable management of any wetland (Imteazzaman and Galib, 2013).

Some research activities have been conducted on ichthyofaunal diversity in different waterbodies of Bangladesh (Galib et al., 2009, 2013; Imteazzaman and Galib, 2013; Ahmed et al., 2004; Zafar et al., 2007; Mohsin et al., 2013; Saha and Hossain, 2002). However, yet no research work has been published on ichthyofaunal diversity of the Juri River. Therefore, the present study was undertaken to prepare a checklist of fish species focusing on their relative present availability status compared to the national conservation status of Bangladesh by IUCN (2015). Thus, the information from this research work is supposed to provide a baseline dataset for carrying out further in-depth investigation on aquatic ecology, conservation, and sustainability for the proper management of fisheries resources of this river.

\section{MATERIALS AND METHODS}

\section{Study area}

This study was carried out at three fishing spots of the Juri River: Gilachhara and Purbo-Badidewli under Gilachhara union, and Pitaitikor under Fenchuganj union of Fenchuganj upazila in Sylhet district. Among $56 \mathrm{~km}$ of the total river length about $12 \mathrm{~km}$ from connecting point from the Kushiyara River to the Sonai-Bardan point was selected for data collection (Figure 1). The primary criteria for the selection of study area were a suitable geographical coverage for wide variety of fish biodiversity and good numbers of fishermen depended on fishing for their livelihood.

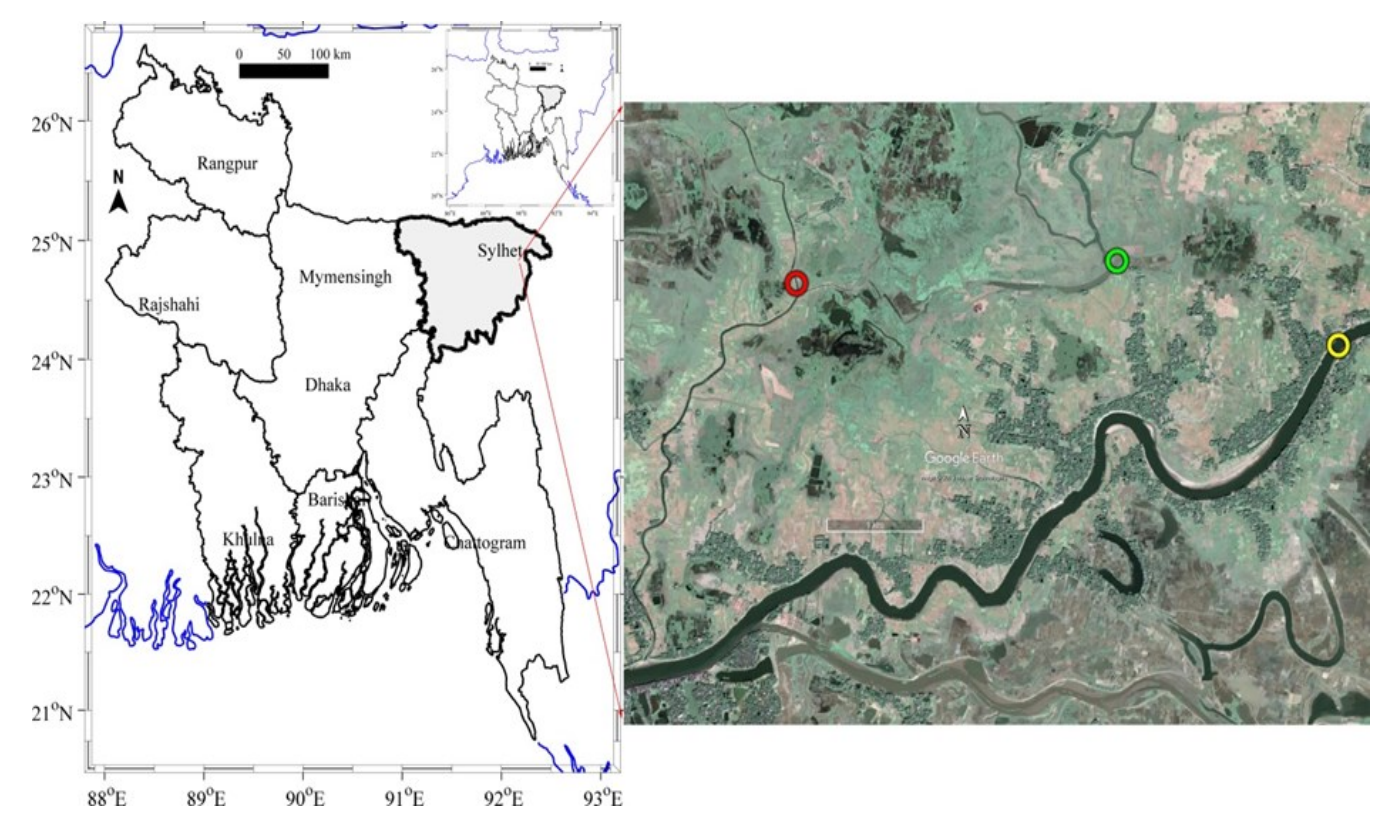

Figure 1. Map showing locations of the study sites in Google Earth Pro map (Pitaitikor, Gilachhara, and Purbo Badiadewli are shown by red, green and yellow circles, respectively). 
Study period and target group

This study was conducted for a period of eight months from May to December, 2018. During the study period several field visits were made to collect necessary information. Different levels of stakeholders of fisheries like fishermen, aratdars (wholesalers), fish retailers and local leaders engaged in fishing, fish marketing and other related activities in the study areas who were wellknown about the Juri River biodiversity were considered as target group. A total of 90 fishermen, 20 fish retailers, 10 aratdars (wholesalers), and 5 local leaders were randomly selected for questionnaire interviews from the selected three study sites.

\section{Preparation of questionnaire}

A draft questionnaire was prepared keeping in view the objectives of the study. Then that draft questionnaire was used for pre-testing with few sample respondents. In pre-testing, attention was paid to incorporate any new information, which was not designed to be asked and filled in the draft interview schedule. The questionnaire was then modified and rearranged according to the experience gathered from the pretest. Thus, the questionnaire was finalized by arranging the questions in such a logical sequence so that the fishermen could answer chronologically.

\section{Collection of data}

Both primary and secondary sources of data were considered for collection in the present study. Primary data were collected from fishermen, aratdars and fish traders through direct catch observation, questionnaire interview (QI), focus group discussion (FGD), and key informant interview (KII) (Arefin et al., 2018; Gebre, 2015). The secondary information was collected from upazila fisheries office of Fenchuganj, district fisheries office of Sylhet, books, journals, MS thesis, published articles, and different internet sources.

\section{Focus group discussion}

A total of 3 FGDs were made at the three villages as mentioned before. The participants of FGD were fishermen of different ages: young, middle aged and old aged.

\section{Questionnaire interview}

A total of 90 fishermen, 10 aratders and 20 fish retailers were randomly selected for QIs from 3 selected villages.

\section{Cross checking of information with key informants}

After collection of data through FGDs and QIs the information were justified by KII. KIls were conducted with key resource persons, such as highly experienced fishers, upazila fisheries officer (UFO), district fisheries officer (DFO), local leaders, and workers from non-government organization (NGO) like Center for Natural Resource Study (CNRS).

Identification of ichthyofauna

Samples of different fish species were collected from the fisher- men's catch landed at different fish landing centers of the selected sampling stations and from fish markets as well. The fish species were identified and sorted based on their external morphology (Rahman, 2005; IUCN, 2015). Then, on the basis of QI and catch records of 90 fishermen the collected species were categorized in four statutes: commonly available (CA) which were observed throughout the year; moderately available (MA) which were observed infrequently in the study area; less available (LA) which were observed infrequently and less amount in the study area, and rarely available (RA) species which were observed fortuitously once or twice in a year. The species of the collected fishes were verified based on IUCN red list (IUCN, 2015) and internet source (http://www.fishbase.org).

\section{Statistical analysis}

After the collection the data were documented in a computer, and were analyzed by using Microsoft Office Excel 2010 to assess the present status of fish biodiversity in the Juri River. For the presentation of the analyzed data, table, pie-chart and bar diagrams were used in the results.

\section{RESULTS AND DISCUSSION}

\section{Ichthyofaunal diversity status}

The Juri River is naturally rich in aquatic biodiversity, mainly fishes, because of its location as an interconnecting water body with the Hakaluki haor and as a tributary of the Kushiyara River. This river ecosystems play a vital role in supporting the biodiversity of fishes, and contributes in animal protein supply as well as to the economy of Bangladesh. For the estimation of abundance and biodiversity status, the identified ichthyofauna were characterized as different levels of threatened conditions such as critically endangered (CR), endangered (EN), vulnerable (VU), near threatened (NT), and least concern (LC) (IUCN, 2015).

During the study period in accordance with the speech of local fishermen as well as direct catch observation and market visits' the fishes were categorized as 11 species were CA, 32 species were MA, 25 species were LA, and 7 species were found as RA in the study area (Figure 1). The recorded total number of fishes with their family details, present status and IUCN status are described in Table 1. In the present study a total of 75 fish species under 25 families were recorded which is higher than the results of Rahman et al. (2015) who recorded a total of 56 species of fishes belonging to 21 families from the Talma River at northern part of Bangladesh. Kamrujjaman and Nabi (2015) documented 48 species of fishes belonging to 18 families in the Bangshi River of Savar. Ali et al. (2014) found 53 species of fishes in the Chitra River at the south-western part of Bangladesh. Mohsin et al. (2014) documented 53 fish species belonging to 28 families at the Andharmanik River in Patuakhali district. Galib et al. (2013) found a total of 63 fish species in the river of Choto Jamuna at Naogaon district, Bangladesh. Islam et al. (2015c) recorded 61 species of fishes from the Sibsa River at southwestern part of Bangladesh. Thus, the species diversity of the Juri River is much higher than those rivers. However, 
Gain et al. (2015) identified a total of 95 finfish species contributing to 45 families at the Passur River of Bangladesh that is higher than present study. Joadder et al. (2015) identified and recorded 71 fish species belonging to 26 families from the river Padma which is closely similar with the present study.

Table 1. Fish species occurrence in the studied area with their IUCN (2015) status.

\begin{tabular}{|c|c|c|c|c|c|c|}
\hline S.N. & Family name & Local name & $\begin{array}{l}\text { Common } \\
\text { name }\end{array}$ & Scientific name & $\begin{array}{c}\text { Present } \\
\text { status }\end{array}$ & $\begin{array}{l}\text { IUCN } \\
\text { status }\end{array}$ \\
\hline 1 & Cyprinidae & Jatpunti & Punti barb & Puntius sophore & CA & $\mathrm{LC}$ \\
\hline 2 & & Sarpunti & Olive barb & Puntius sarana & LA & NT \\
\hline 3 & & Tit punti & Ticto barb & Puntius ticto & RA & VU \\
\hline 4 & & Mola punti & Glass barb & Puntius guganio & MA & LC \\
\hline 5 & & Gonia & Kuria labeo & Labeo gonius & CA & NT \\
\hline 6 & & Kalibaus & Black rohu & Labeo calbasu & CA & LC \\
\hline 7 & & Bata & Bata labeo & Labeo bata & MA & LC \\
\hline 8 & & Rui & Rohu carp & Labeo rohita & LA & LC \\
\hline 9 & & Agun chokha & Angra labeo & Labeo angra & RA & LC \\
\hline 10 & & Naukka chela & Gora chela & Securicula gora & MA & NT \\
\hline 11 & & Fulchela & $\begin{array}{l}\text { Finescale razorbelly } \\
\text { minnow }\end{array}$ & Salmostama phulo & CA & NT \\
\hline 12 & & Narkali chela & Large razorbelly minnow & Salmostoma bacalia & LA & LC \\
\hline 13 & & Chap chela & Sind danio & Dvario devario & LA & LC \\
\hline 14 & & Mola & Mola carplet & Amblypharyngodon mola & LA & LC \\
\hline 15 & & Dhela & Cotio & Osteobrama cotio & RA & NT \\
\hline 16 & & Darkina & Flying barb & Esomus danricus & LA & LC \\
\hline 17 & & Lachu & Reba carp & Cirrhinus reba & MA & NT \\
\hline 18 & & Mrigel & Mrigal & Cirrhinus cirrhosus & LA & NT \\
\hline 19 & & Carpu & Common carp & Cyprinus carpio & LA & LC \\
\hline 20 & & Catla & Catla & Catla catla & LA & LC \\
\hline 21 & Bagridae & Tengra & Striped dwarf catfish & Mystus vittatus & MA & LC \\
\hline 22 & & Kalo bujuri & Tengara mystus & Mystus tengara & MA & LC \\
\hline 23 & & Gulsha & Gangetic mystus & Mystus cavasius & CA & NT \\
\hline 24 & & Loitta Tengra, Gulsha & Day's mystus & Mystus bleekeri & MA & LC \\
\hline 25 & & Gang Tengra & Menoda catfish & Hemibagrus menoda & LA & NT \\
\hline 26 & & Rita & Rita & Rita rita & RA & EN \\
\hline 27 & & Ayre & Long whiskered catfish & Sperata aor & MA & VU \\
\hline 28 & & Guizza ayre & Giant river catfish & Sperata seenghala & RA & VU \\
\hline 29 & Siluridae & Boal & Freshwater shark & Wallago attu & CA & VU \\
\hline 30 & & Kani pabda & Two spot glass catfish & Ompok bimaculatus & LA & $\mathrm{EN}$ \\
\hline 31 & Channidae & Madhu Pabda & Butter catfish & Ompok pabda & MA & EN \\
\hline 32 & & Taki & Spotted snakehead & Channa punctatus & CA & LC \\
\hline 33 & & Cheng & Walking snakehead & Channa orientalis & MA & LC \\
\hline 34 & & Shol & Striped snaked & Channa striatus & LA & LC \\
\hline 35 & & Gozar & Giant snakehead & Channa marulius & MA & EN \\
\hline 36 & Mastacembelidae & Boro baim & Tire-track spiny eel & Mastacembelus armatus & CA & EN \\
\hline 37 & & Guchi baim & Striped spinyeel & Macrognathus pancalus & MA & LC \\
\hline 38 & & Tara baim & One-stripe spinyeel & Macrognathus aculeatus & MA & NT \\
\hline 39 & Anabantidae & Koi & Climbing perch & Anabas testudineus & MA & LC \\
\hline 40 & Osphronemidae & Khalisha & Banded gourami & Trichogaster fasciata & MA & LC \\
\hline 41 & & Lal khalisha & Dwarf gourami & Trichogaster lalius & MA & LC \\
\hline 42 & Notopteridae & Chital & Humped featherback & Notopterus chitala & MA & EN \\
\hline 43 & & Foli & Grey featherback & Notopterus notopterus & LA & VU \\
\hline
\end{tabular}


Table 1. Continued.

\begin{tabular}{|c|c|c|c|c|c|c|}
\hline 44 & Sisoridae & Baghair & Dwarf goonch & Bagarius bagarius & $\mathrm{LA}$ & CR \\
\hline 45 & Cobitidae & Bou, rani & Necktie loach & Botia dario & CA & EN \\
\hline 46 & & Gutum & Guntea loach & Lepidocephalus guntea & MA & $\mathrm{LC}$ \\
\hline 47 & & Gutum & Annandalei loach & $\begin{array}{l}\text { Lepidocephalichthys } \\
\text { annandalei }\end{array}$ & LA & VU \\
\hline 48 & & Puiya & Burmese loach & $\begin{array}{l}\text { Lepidocephalichthys } \\
\text { berdmorei }\end{array}$ & LA & LC \\
\hline 49 & Clupeidae & Ilish & Hilsa shad & Tenualosa ilisha & RA & LC \\
\hline 50 & & Chapila & Indian river shad & Gudusia chapra & MA & VU \\
\hline 51 & & Kachki & Ganges river sprat & Corica soborna & MA & LC \\
\hline 52 & Schilbeidae & Bacha & Batchwa vacha & Eutropiichthys vacha & MA & LC \\
\hline 53 & & Gharua, laira & Garua bacha & Clupisoma garua & LA & EN \\
\hline 54 & & Batasi & Indian potasi & Neotropius atherinoides & MA & LC \\
\hline 55 & & Kajuli & Gangetic ailia & Ailia coila & MA & LC \\
\hline 56 & & Hilon & Silond catfish & Silonia silondia & RA & LC \\
\hline 57 & Palaemonidae & Golda & Gaint freshwater prawn & Macrobrachium rosenbergii & MA & LC \\
\hline 58 & & Gura icha & Kuncho river prawn & Macrobrachium lamarrei & CA & LC \\
\hline 59 & & Kaira icha & Kaira river prawn & Macrobrachium dayanum & MA & $\mathrm{LC}$ \\
\hline 60 & Nandidae & Meni & Mud perch & Nandus nandus & MA & NT \\
\hline 61 & Heteropneustidae & Shing & Stinging catfish & Heteropneustes fossilis & LA & LC \\
\hline 62 & Clariidae & Magur & Walking catfish & Clarias batrachus & LA & LC \\
\hline 63 & Gobiidae & Bele & Tank goby & Glossogobius giuris & MA & LC \\
\hline 64 & & Bele & Tiger goby & Eugnathogobius oligactis & LA & VU \\
\hline 65 & & Lomba chanda & Elongate glass-perchlet & Chanda nama & MA & LC \\
\hline 66 & & Gol chanda & Indian glass fish & Parambassis ranga & MA & LC \\
\hline 67 & & Lal chanda & Highfin glassy perchlet & Parambasis lala & LA & LC \\
\hline 68 & Cichlidae & Tilapia & Mozambique tilapia & Oreochromis mossambicus & LA & LC \\
\hline 69 & Balitoridae & $\begin{array}{l}\text { Bilturi, } \\
\text { balichata }\end{array}$ & Sand loach & Acanthocobitis botia & LA & LC \\
\hline 70 & Belonidae & Kakila & Frashwater garfish & Xenentodon cancila & MA & LC \\
\hline 71 & Hemiramphidae & Ekthota & Congaturi halfbeak & Hyporamphus limbatus & LA & LC \\
\hline 72 & Sciaenidae & Kuli & Cuja croaker & Macrospinosa cuja & MA & NT \\
\hline 73 & Anguillidae & Bamos & Indian mottled eel & Anguilla bengalensis & MA & VU \\
\hline 74 & Sybranchidae & Kuchia & Gangetic mudeel & Monopterus cuchia & LA & VU \\
\hline 75 & Tetraodontidae & Potka & Ocellated pufferfish & Tetraodon cutcutia & $\mathrm{CA}$ & $\mathrm{LC}$ \\
\hline
\end{tabular}

${ }^{*} \mathrm{CA}=$ commonly available, $\mathrm{MA}=$ moderately available, $\mathrm{LA}=$ less available, $\mathrm{RA}=$ rarely available,${ }^{*} \mathrm{CR}=$ critically endangered, $\mathrm{EN}=$ endangered, $\mathrm{VU}=$ vulnerable, NT = near threatened and LC = least concern.

From the record of the study Cyprinidae was the most leading family among the 25 families containing maximum fish species (20) which consists of $27 \%$ of the total ichthyofauna species. Bagridae (11\%) was the second most leading family comprising 8 fish species followed by 5 species of Schilbeidae and Gobiidae (7\%), 4 species of Channidae and Cobitidae (6\%), 3 species of Mastacembelidae, Siluridae, Clupeidae and Palaemonidae (4\%), 2 species of Osphronemidae and Notopteridae (3\%), 1 species of each family were found under Anabantidae, Sisoridae, Nandidae, Heteropneustidae, Clariidae, Cichlidae, Balitoridae, Belonidae, Hemiramphidae, Sciaenidae, Anguillidae, Sybranchidae and Tetraodontidae (1\%) (Figure 2).

Similar findings of Cyprinidae as a major family were also reported for many other rivers of Bangladesh with differences of number of species. For instance, Joadder et al. (2015) found Cyprinidae as dominant family with 23 species of fishes at the Padma River. Galib (2015) identified Cyprinidae family as dominant with 15 species at the river Brahmaputra. Islam et al. (2016) found Cyprinidae as highest contributing family with highest number (10) of species at the Jamuna River of Bangladesh. Chaki et al. (2014) documented Cyprinidae as the most dominating fish family consisting of 18 fish species in the Atrai River of Bangladesh. Mohsin et al. (2013) recorded Cyprinidae as the most dominant fish family containing of 22 species of fishes in the Padma River of Rajshahi district. However, dominant fish species of the Cyprinidae family was different in many rivers of Bangladesh which might be due to geographical and environmental differences of those rivers.

According to the present study, 7 fish species were rarely available in the study sites (Figure 3). The rarely available species are those fish species which passing a very critical condition that will be disappeared in near future. In percentage, MA species consists $43 \%$ of the total recorded fish species followed by LA (33\%), CA (15\%) and RA (9\%) (Figure 4). Kamrujjaman and Nabi (2015) found 29 species (40.42\%) of fishes as locally rare, only 3 species (6.25\%) of fishes were very common and 16 species (33.33\%) were common in the Bangshi River. Islam et al. (2015b) recorded 24 commonly available, 16 moderately available, 18 rarely available species of fishes from the wetlands of Sylhet district. Islam et al. (2015a) recorded as available (43.86\%), less available (29.82\%), rare (18.42\%) and very rare (7.89\%) species 
of fishes at the Payra River of Bangladesh. Gain et al. (2015) recorded $50 \%$ of the fishes as available followed by $26 \%$ less available, $16 \%$ rare and $8 \%$ very rare in the Passur River of Bangladesh. Arefin et al. (2018) found 14 species as commonly available (23\%), 28 species as moderately available (45\%), and 20 species as rarely available (32\%). The number and percentage of available fish species found in the present study is slightly different with the above studies which might be due to the differences of geographical location, study duration, and difference of availability of fishes in the study periods.

In the present survey gulsha (Mystus cavasius) was documented as the most abundant fish species among the 11 commonly available species. Boro baim (Mastacembelus armatus) was the second most abundant species followed by jatpunti (Puntius sophore), rani (Botia dario), gonia (Labeo gonius), kalibasu (Labeo calbasu), gura chingri (Macrobrachium lamarrei), boal (Wallago attu), fulchela (Salmostama phulo), potka (Tetraodon cutcutia), and taki (Channa punctatus). Similar findings were also found in various studies on several small rivers. Kamrujjaman and Nabi (2015) recorded the most dominated species kalo bujuri (Mystus tengra) and jatpunti (Puntius sophore) from the Bangshi River of Bangladesh. Imteazzaman and Galib (2013) documented jatpunti as the most abundant fish species in the Halti beel of Bangladesh. Hossain et al. (2009) recorded jatpunti, tit punti (Puntius ticto) followed by chanda (Chanda nama and Parambassis ranga), chapila (Gudusia chapra) and tengra (Mystus vittatus) as the most abundant fish species in the Chalan beel of Bangladesh.

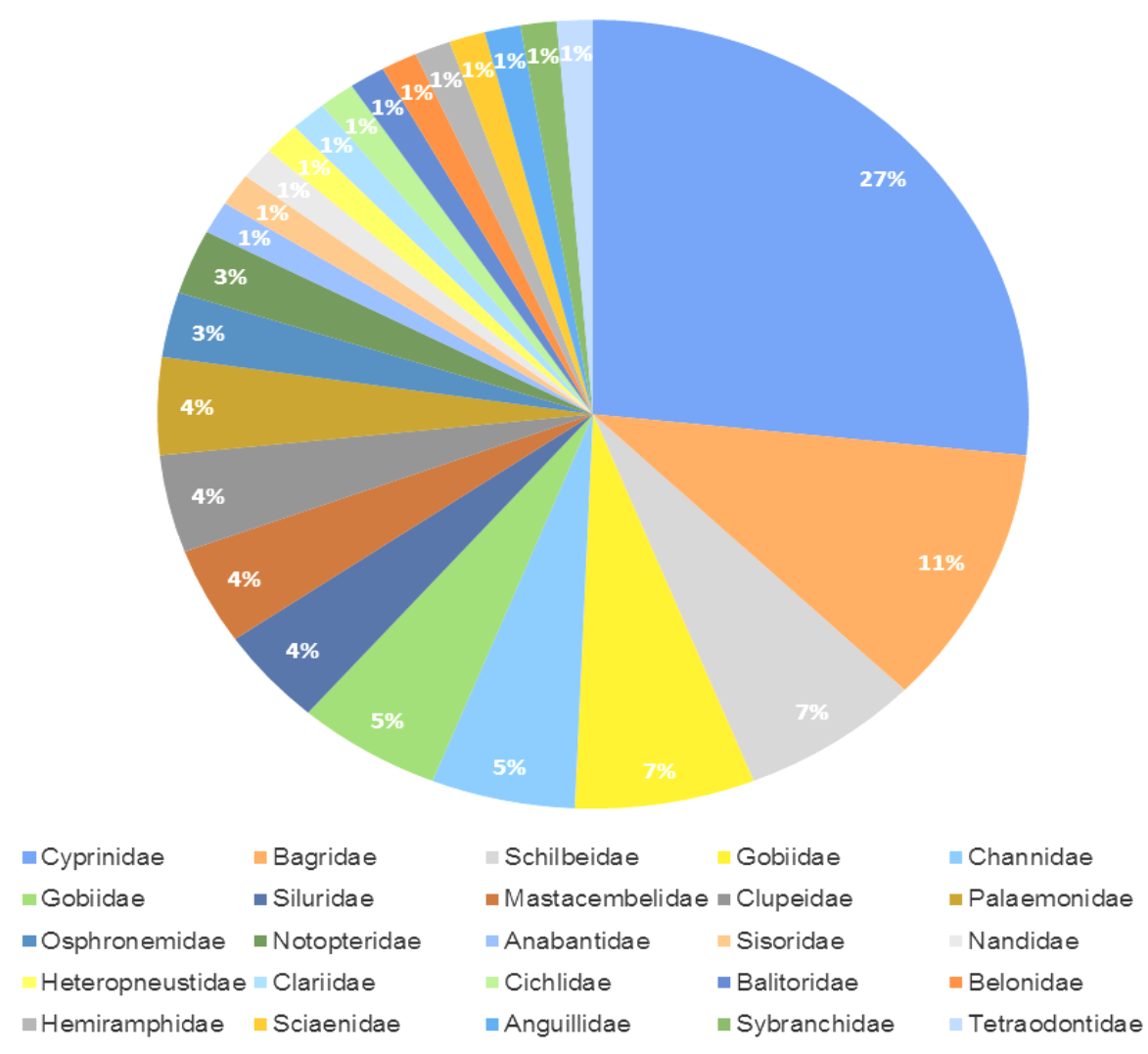

Figure 2. Percentage of fish species diversity under different families recorded in the Juri River.

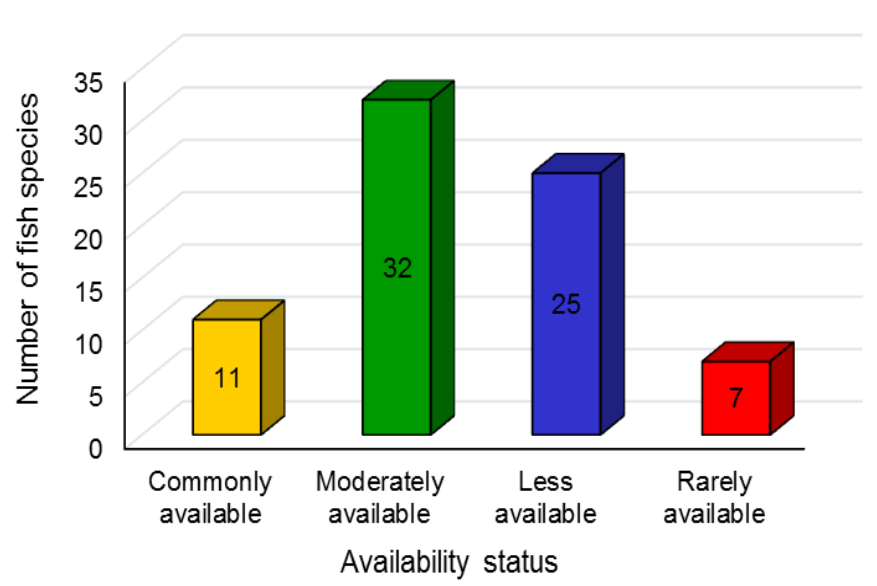

Figure 3. Status of ichthyofaunal diversity in the study area.

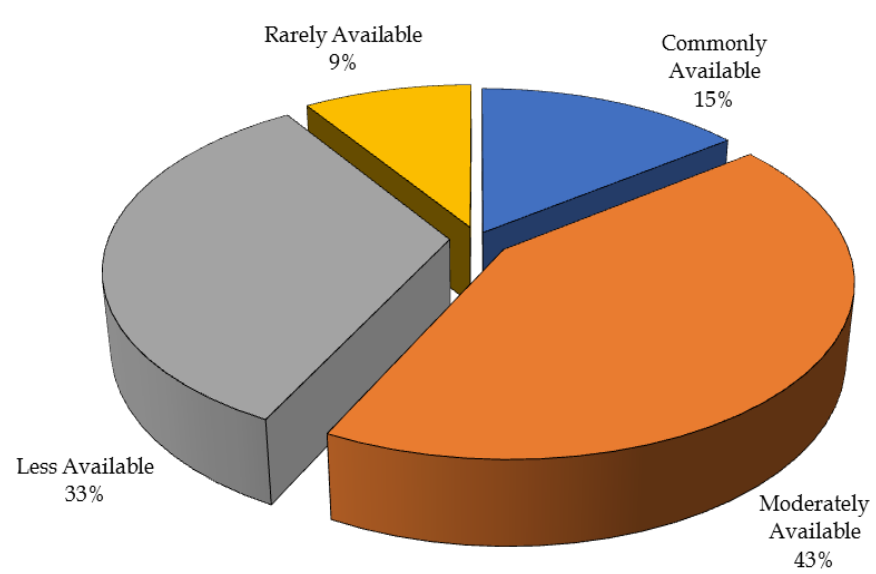

Figure 4. Percentage of fish biodiversity in the study area. 


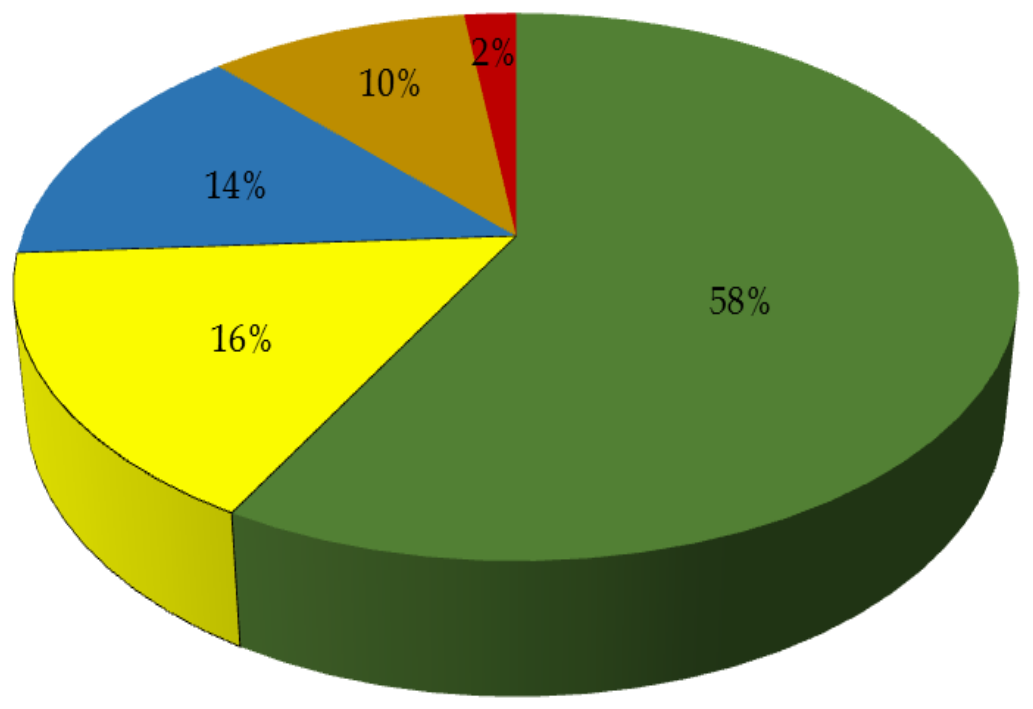

\section{- Least concern $\square$ Near thretened $\square$ Vulnerable Endangered $\square$ Critically endangered}

Figure 5. Percentage of fish species according to IUCN status.

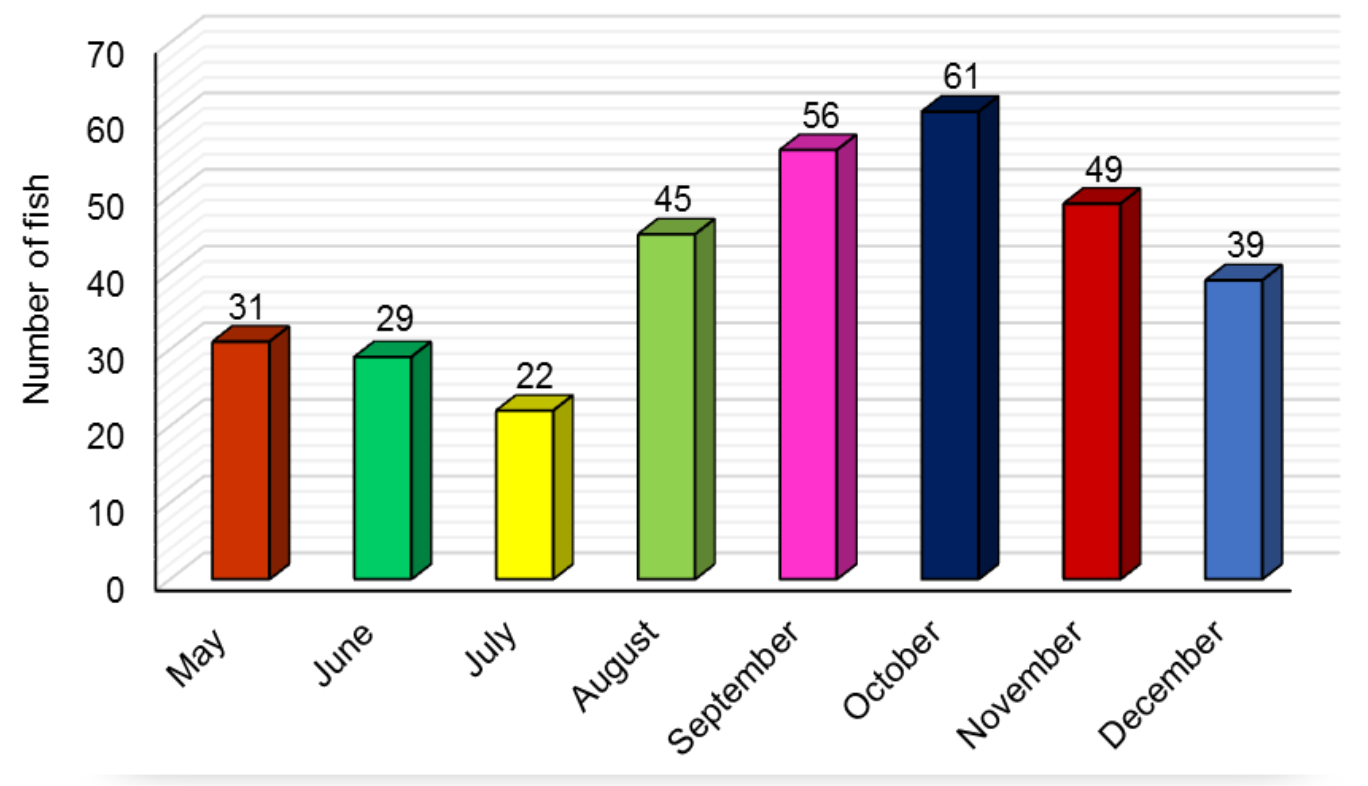

Name of the month

Figure 6. Monthly variation of fish species availability.

Biodiversity of threatened ichthyofauna species

Out of the recorded 75 fish species, 44 species LC, 12 species NT, 10 species VU, 8 species EN, and 1 species CR were recorded from the Juri River (IUCN, 2015). According to the present study vulnerable species were ayre (Sperata aor) and guizza ayre (Sperata seenghala) of Bagridae family, tit punti (Puntius ticto) of Cyprinidae family, boal (Wallago attu) of Siluridae family, foli (Notopterus notopterus) of Notopteridae family, gutum (Lepidocephalichthys annandalei) of Cobitidae family, chapila (Gudusia chapra) of Clupeidae family, bele (Eugnathogobius oligactis) of Gobiidae family, bamos (Anguilla bengalensis) of Anguillidae family, kuchia (Monopterus cuchia) of Sybranchidae family. Among the 8 EN species, kani pabda (Ompok bimaculatus) and modhu pabda (Ompok pabda) were identified under the family of Siluridae, gozar (Channa marulius) of Channidae family, boro baim (Mastacembelus armatus) of Mastacembelidae family, rita (Rita rita) of Bagridae family, chital (Notopterus chitala) of Notopteridae family, rani (Botia dario) of Cobitidae family, and gharua (Clupisoma garua) of Schilbeidae family.

A single CR species is baghair (Bagarius bagarius) under the family of Sisoridae. The CR are those fish species which passing a very critical condition that will be disappeared in near future. During the study period 2 species were recorded as extinct which were available one or two decades ago. These 2 species named- mohashol (Tor tor), and nandina (Labeo nandina) were documented frequently as extinct. Conversely, it was informed that the CR fish species would be extinct in near future. 
In percentage, among the five categories (IUCN, 2015) of available 75 fish species, LC species consists $58 \%$, NT species consists $16 \%$, VU species consists $14 \%$, EN species consists $10 \%$, and CR consists $2 \%$ (Figure 5). Here, 19 fish species (26\% of the total recorded species) were recorded as threatened species. Joadder et al. (2015) recorded 28 species of fishes as threatened by IUCN at the river Padma and categorized as VU (13\%), EN (18\%), and CE (8\%). Kamrujjaman and Nabi (2015) documented $52.08 \%$ threatened species in the Bangshi River of Bangladesh in which VU, EN and CE were $20 \%, 36 \%$ and $44 \%$, respectively. Rahman et al. (2015) revealed that $32.14 \%$ of fish species were threatened in the Talma River of northern part of Bangladesh, and documented $12.5 \%$ as VU, $16.07 \%$ as EN and $3.57 \%$ as CE species among the total threatened fish species. Chaki et al. (2014) identified 30 locally threatened species among which VU 13.51\%, EN 18.92\%, and CE 8.11\% were recorded at the Atrai River of Bangladesh. Galib et al. (2013) found $41.27 \%$ species threatened including 15.87\% VU, 15.87\% EN and 9.52\% CE fish species at the river Choto Jamuna of Bangladesh. Mohsin et al. (2013) considered 26 species threatened by IUCN Bangladesh including VU (13.04\%), EN (13.04\%) and CE (8.70\%) of the total fish species from the Padma River at Rajshahi district. The threatened fish species with their various percentages of categories of different small and big rivers of Bangladesh slightly too largely differed from the present study due to various manmade and natural factors.

During the survey with the respondents of the present study, two species of fishes namely mohashol and nandina were not found in the study area which were available before 10-20 years. Chakraborty and Mirza (2010) studied and recorded six important commercial aquatic species, mohashol, nandina, olive barb and reptiles as extinct species from the Someswari River during 2001-2005. The excess fishing pressure, different geographical locations, water flow, and suitability of feeding, breeding and nursing grounds of different waterbodies cause different calculation and identification of threatened fish species from the Juri River.

\section{Monthly variation in fish availability}

During this study maximum number of species (61) were found in October followed by September (56), August (45), November (49), December (39), May (31), June (29), and lowest numbers of species (22) in July. However, in the study area the amount of fish caught was abundant during September to November (Figure 6). The availability and abundance of the fish as observed during the period of study were closely related to seasonal variations and fishes were found to be more available in the Juri River immediately after rainy season. With exceptions of a few occasions, fishes were available round the year. However, all species could not be easily caught by the used fishing gears due to the extent of water flow and depth variation in the river basin. Khan et al. (2018) recorded maximum number of fish species from Kolavanga beel during the month of August (35) followed by September (29) and October (25).

Ahmed (1997) observed that seasonal fluctuation in the fish species is a normal phenomenon and concluded that some species were found throughout the year. Haque (2013) recorded 31 species of fish in Baikka beel. The maximum number of species in both wetlands was found during the month of August. It was reported by all the respondents that the availability of fishes has been declining due to various manmade and natural reasons.

\section{Conclusion}

The Juri River is naturally an aquatic resourceful river in the north-eastern part of Bangladesh. Since, it is an interconnecting body of water between two important waterbodies of Sylhet region (Hakaluki haor and the Kushiyara River) its ecosystem plays a dynamic role in supporting the ichthyofaunal diversity. It was perceived from the fishers and visiting fish markets around the study area that about $42 \%$ species of fishes were less available and rarely available which might be disappeared from the study area in near future. From the statement of the respondent's habitat degradation, climate change, and human activities are found to be responsible for ichthyofaunal diversity loss in the Juri River. It can be concluded that proper management measures should be taken including community participation to conserve the overall aquatic ecosystem and enhance fish production in the Juri River of Sylhet district in Bangladesh.

\section{Conflict of interest}

The authors declare there are no conflicts of interest.

Open Access: This is an open access article distributed under the terms of the Creative Commons Attribution 4.0 License, which permits unrestricted use, distribution, and reproduction in any medium, provided the original author(s) if the sources are credited.

\section{REFERENCES}

Ahmed, N. (1997). Marketing of fish from selected floodplains in Bangladesh. In: Open water fisheries of Bangladesh. The University Press Limited, Dhaka1000. pp. 72.

Ahmed, K.K.U., Hasan, K.R., Ahamed, S.U., Ahmed, T. and Mustafa, G. (2004). Ecology of Shakla beel (Brahmanbaria), Bangladesh. Bangladesh Journal of Fisheries Research, 8: 101-111.

Ali, M.M., Hossain, M.B., Rahman, M.A. and Habib, A. (2014). Diversity of fish fauna in the Chitra River of South-Western Bangladesh: present status, threats and recommendations for conservation. Asian Journal of Applied Sciences, 7 (7): 635-643, https://scialert.net/abstract/?doi=ajaps.2014.635.643

Arefin, S., Kunda, M., Islam M.J., Pandit, D. and Haque, A.T.U. (2018). Status of fish and shellfsh diversity and their decline factors in the Rupsa River of Khulna in Bangladesh. Archives of Agriculture and Environmental Science, 3(3): 232239, https://dx.doi.org/10.26832/24566632.2018.030304

Chaki, N., Jahan, S., Fahad, M.F.H., Galib, S.M. and Mohsin A.B.M. (2014). Environment and fish fauna of the Atrai River: global and local conservation perspective. Journal of Fisheries, 2(3): 163-172, https://doi.org/10.17017/jfish.v2i3.2014.46

Chakraborty, B.K. and Mirza, M.J.A. (2010). Status of aquatic resources in Someswari River in Northern Bangladesh. Asian Fisheries Science, 23: 174-193.

DoF, Department of Fisheries (2018). National Fish Week Compendium 2018 (In 
Bangali). Department of Fisheries, Ministry of Fisheries and Livestock, Bangladesh. pp. 160.

Gain, D., Mahfuj, M.S.E., Sultana, S. and Mistri, N.A. (2015). A preliminary study on fish fauna of the Passur River in Bangladesh. International Journal of Biodiversity and Conservation, 7(7): 346-353.

Galib, S.M. (2015). Fish fauna of the Brahmaputra River, Bangladesh: richness, threats and conservation needs. Journal of Fisheries, 3(3): 285-292, https://doi.org/10.17017/jfish.v3i3.2015.120

Galib, S.M., Naser, S.M.A., Mohsin, A.B.M., Chaki, N. and Fahad, F.H. (2013). Fish diversity of the River Choto Jamuna, Bangladesh: present status and conservation needs. International Journal of Biodiversity and Conservation, 5 (6): 389-395, http://dro.dur.ac.uk/21391/1/21391.pdf

Galib, S.M., Samad, M.A., Mohsin, A.B.M., Flowra, F.A. and Alam, M.T. (2009). Present status of fishes in the Chalan Beel-the largest Beel (wetland) of Bangladesh. International Journal of Animal and Fisheries Science, 2 (3): 214-218.

Gebre, M., 2015. College of Development Studies Food Security Studies (Doctoral dissertation, Addis Ababa University).

Haque, M.M.U. (2013). Impacts of Baikka beel sanctuary on protection and restoration of fish diversity and enhancement of local livelihoods. Connecting communities and conservation: Co-management initiatives by IPAC in Wetlands and Forests of Bangladesh. USAID/Bangladesh. pp. 177-191.

Hossain, M.A., Nahiduzzaman, M., Sayeed, M.A., Azim, M.E., Wahab, M.A. and Olin, P.G. (2009). The Chalan beel in Bangladesh: habitat and biodiversity degradation, and implications for future management. Lakes \& Reservoirs: Research \& Management, 14(1): 3-19, https://doi.org/10.1111/j.1440-1770.2009.00387.x

Hossain, M.A.R. (2014). An overview of fisheries sector of Bangladesh. Research in Agriculture Livestock and Fisheries, 1(1): 109-126, https://doi.org/10.3329/ralf.v1i1.22375

Imteazzaman, A.M. and Galib, S.M. (2013). Fish Fauna of Halti Beel, Bangladesh. International Journal of Current Research, 5(1): 187-190.

Islam, M.A., Hossain, M.M., Ahsan, M.E. and Nahar, A. (2015a). Status and current worries of fish diversity in the Payra River, Patuakhali, Bangladesh. International Journal of Fisheries and Aquatic Studies, 2(3): 160-165.

Islam, M.A., Islam, M.Z., Barman, S.K., Morshed, F. and Marine, S.S. (2015b). Study on present status of fish biodiversity in wetlands of Sylhet District, Bangladesh. Agriculture, Forestry and Fisheries, 4: 296-299.

Islam, M.K., Habib, K.A., Ahsan, M.E., Ali, M.M. and Basak, S.K. (2015c). Fish biodiversity at Sibsa River in South-Western Bangladesh: status and conservation Requirements. International Journal of Fisheries and Aquatic Studies, 4(6): 24-28, https://doi.org/10.11648/j.aff.20150406.20

Islam, S.M., Rahman, M.B., Alam, M.R., Mithun, B.D., Bal, A., Azam, M. and Ruma, M.
(2016). A case study on fishing gears, fish Species composition and Fisher folk community at Jamuna River of Sirajganj Sadar Fish Landing Site, Bangladesh. Journal of Aquatic Science, 4(1): 11-19, http://pubs.sciepub.com/jas/4/1/2

IUCN, B. (2015). Red list of Bangladesh, Volume 5: Freshwater Fishes. IUCN, International Union for Conservation of Nature, Bangladesh country office, Dhaka, Bangladesh, pp. 29.

Joadder, M.A.R., Galib, S.M., Haque, S.M.M. and Chaki, N. (2015). Fishes of the river Padma, Bangladesh: current trend and conservation status. Journal of Fisheries, 3(2): 259-266.

Kamrujjaman, M. and Nabi, M.R. (2015). Ichthyodiversity of the Bangshi River, Savar, Dhaka. Jahangirnagar University Journal of Biological Sciences, 4(1): 19-25, https://doi.org/10.3329/jujbs.v4i1.27782

Khan, M.A.R., Ali, M.M., Salam, M.A., Kunda, M. and Pandit, D. (2018). Impact of fish sanctuary on Fish Biodiversity and Livelihoods of Fishermen in Kolavanga beel of Bangladesh. World Journal of Fish and Marine Sciences, 10(5): 46-54; https://idosi.org/wjfms/wjfms10(5)18/1.pdf

Mazid, M.A. (2010). Development of fisheries in Bangladesh: plans and strategies for income generation and poverty alleviation. Momin Offset Press, Dhaka.

Mohsin, A.B.M., Haque, S.M.M., Galib, S.M., Fahad, M.F.H., Chaki, N., Islam, M.N. and Rahman, M.M. (2013). Seasonal abundance of fin fishes in the Padma River at Rajshahi district, Bangladesh. World Journal of Fish and Marine Sciences, 5(6): 680-685, http://idosi.org/wjfms/wjfms5(6)13/18.pdf

Mohsin, A.B.M., Yeasmin, F., Galib, S.M., Alam, B. and Haque, S.M.M. 2014: Fish fauna of the Andharmanik River in Patuakhali, Bangladesh. Middle-East Journal of Scientific Research, 21(5): 802-807.

Rahman, A.K.A. 2005. Freshwater fishes of Bangladesh. Second edition, Zoological Society of Bangladesh, Dhaka, Bangladesh. 394 pp.

Rahman, M.A., Mondal, M.N., Hannan, M.A. and Habib, K.A. (2015). Present status of fish biodiversity in Talma River at Northern Part of Bangladesh. International Journal of Fisheries and Aquatic Studies, 3(1): 341-348.

Rahman, M.M., Hossain, M.Y., Ahamed, F., Fatematuzzhura, Subba, B.R., Abdallah, E.M. and Ohtomi, J. (2012). Biodiversity in the Padma distributary of the Ganges River, North-Western Bangladesh: recommendations for conservation. World Journal of Zoology, 7(4): 328-337.

Saha, B.K. and Hossain, M.A. (2002). Saldu beel fishery of Tangail. Bangladesh Journal of Zoology, 30(2): 187-194.

Shamsuzzaman, M.M., Islam, M.M., Tania, N.J., Al-Mamun, M.A., Barman, P.P. and Xu, X. (2017). Fishery's resources of Bangladesh: Present status and future direction. Aquaculture and Fisheries, 2(4): 145-156, https://doi.org/10.1016/j.aaf.2017.03.006

Zafar, M.S., Amin, M.N. and Iqbal, M.J. (2007). Biodiversity of fisheries organisms in the Pagla river of Bangladesh. Bangladesh Journal of Fisheries, 30: 165-175. 